\section{Production of Commercially Valuable Sized Fruit as a Function of Navel Orange Yield}

\author{
Craig E. Kallsen
}

Additional index words. Citrus sinensis, fruit number, fruit size, fruit yield, production function, San Joaquin Valley

SUMMARY. The relationship between the number of commercially valuable sized fruit produced per unit land area vs. total number of fruit produced per unit land area for mature navel orange (Citrus sinensis) has not been documented. Knowing this relationship, referred to as the commercial fruit production function (CFPF) within this paper, may aid growers in making fruit thinning and tree pruning decisions and researchers in evaluating the interaction of fruit yield and size in response to fruit thinning, tree pruning, variety selection and tree spacing experimentation. For midseason navel oranges in the southern San Joaquin Valley of California, a reliable CFPF for total annual fruit production ranging from 14,000 to 130,000 fruit/acre was found to exist over multiple seasons in three orchards. The CFPF for two early maturing navel orange varieties was not significantly different with respect to slope or intercept from the CFPF for midseason varieties over the range of 12,000 to 63,000 fruit/acre, but became unreliable when fruit number exceeded 63,000 fruit/acre.

S outhern San Joaquin Valley of California conditions are favorable for producing early and midseason navel oranges. Under typical market conditions, the most commercially valuable sized fresh navel oranges produced in California are those with average diameters of 72 to $88 \mathrm{~mm}$. Oranges within this size range are selected and packed so that $88,72,56$, or 48 fruit tightly fill a $37.5-1 b$ commercial carton.

Currently, information is lacking relating the proportion of the most valuable fruit present in a given total yield of navel oranges, or even if a consistent relationship exits. Previous research has demonstrated that yield per tree or unit land area and individual fruit size or weight is related. For example, Parker (1934) demonstrated inverse linear relationships between yield by weight (i.e., the mean number of packed boxes of fruit shipped per acre) and fruit number (i.e., the mean number of fruits per packed box) for both Valencia (C. sinensis) and navel orange. Goldschmidt and Monselise (1977) documented the inverse relationship between the number of fruit per tree and individual fruit weight or size for several citrus species.

Farm Advisor, University of California Cooperative Extension, Kern County, 1031 S. Mt. Vernon Ave., Bakersfield, CA 93307; e-mail: cekallsen@ucdavis.edu

My thanks to L. Ferguson and J. Karlik for reviewing and improving the manuscript, and to the Citrus Research Board in California for its financial assistance.
Previous research, while useful in demonstrating general relationships between yield and fruit size in navel orange, has not been sufficiently detailed to be economically useful to growers. Knowing the relationship between total fruit number produced per unit land area and the number of commercially valuable sized fruit per unit land area, called the commercial fruit production function (CFPF) in this paper, might assist growers in making informed decisions related to fruit thinning, tree pruning and tree spacing. Plant breeders could use the CFPF as an evaluation tool for variety selection. For example, for two varieties with linear CFPFs and similar y-intercepts, the one having a slope value closest to equaling 1 , the theoretical maximum value, would have the highest proportion of valuable sized fruit at any given level of yield. Alternatively, a concave-downward parabolic CFPF or a CFPF approaching a horizontal asymptote or plateau would suggest the existence of a yield level where the production of valuable sized fruit is maximized. For curvilinear CFPFs like these, targeting such a yield level might guide grower fruit thinning, tree pruning or plant spacing (Boswell, 1970, 1975) decisions.

The objective of this study was to determine if a predictively useful CFPF could be demonstrated for early and midseason navel oranges.

\section{Materials and methods}

The calculation of predictively useful CFPFs required a range of data points that relate total annual fruit number per unit land area with numbers of commercially valuable fruit per unit land area. These data points were obtained from the results of blocked, randomized and replicated experimental trials conducted in six mature navel orange orchards from 1996 to 2004 (Table 1). Harvested fruit from the trees assigned to a given replicate within each trial were pooled into bins and trucked to the experimental packline at the University of California Lindcove Research and Extension Center near Exeter, Calif. The objectives and treatments varied among these six experiments, but fruit from experimental plots were similarly evaluated for yield, average size classification, grade, color and pest damage the day following harvest. Each of the replicates within each treatment was included in the calculation of the CFPF. The six orchards, selected based on tree uniformity and health, varied in soil type from loamy sands (Orchard 4) to loam (Orchards 2 and 3 ) to clay loams (Orchard 1, 5 and 6). According to grower records, orchards received nitrogen annually at from $100 \mathrm{lb} /$ acre in Orchard 1 to a maximum $150 \mathrm{lb} /$ acre in Orchard 4. Orchards were irrigated with lowvolume micro-emitter systems except Orchard 4, which was furrow irrigated. The trees in all orchards were grafted on either 'Troyer' or 'Carrizo' citrange (C. sinensis $\mathrm{X}$ Poncirus trofoliata) rootstocks.

Data were analyzed using the General Linear Model statistical package in Statistica software (StatSoft Inc., Tulsa, Okla.). All data measured in each orchard were included in the appropriate regression analysis and no

\begin{tabular}{llll}
\hline $\begin{array}{l}\text { Units } \\
\text { To convert U.S. to SI, } \\
\text { multiply by }\end{array}$ & U.S. unit & SI unit & $\begin{array}{l}\text { To convert SI to U.S., } \\
\text { multiply by }\end{array}$ \\
\hline 0.4047 & acre $(\mathrm{s})$ & $\mathrm{ha}$ & 2.4711 \\
25.4000 & inch $(\mathrm{es})$ & $\mathrm{mm}$ & 0.0394 \\
0.4536 & $\mathrm{lb}$ & $\mathrm{kg}$ & 2.2046 \\
1.1209 & $\mathrm{lb} /$ acre & $\mathrm{kg} \cdot \mathrm{ha}^{-1}$ & 0.8922
\end{tabular}


Table 1. Randomized and replicated experiments in the southern San Joaquin Valley of California used as sources of data for estimating the relationship of commercially valuable sized fruit number per unit land area vs. total fruit number per unit land area for mature navel orange trees.

\begin{tabular}{|c|c|c|c|c|c|c|c|c|}
\hline $\begin{array}{l}\text { Orchard } \\
\text { no. }\end{array}$ & Variety & $\begin{array}{c}\text { Maturity } \\
\text { class }^{\mathrm{z}}\end{array}$ & $\begin{array}{c}\text { Trees } \\
(\text { no./acre })^{y}\end{array}$ & $\begin{array}{c}\text { Treatments } \\
\text { (no.) }\end{array}$ & $\begin{array}{c}\text { Replicates } \\
\text { (no.) }\end{array}$ & $\begin{array}{c}\text { Trees per } \\
\text { replicate (no.) }\end{array}$ & $\begin{array}{c}\text { Crop bloom } \\
\text { year }\end{array}$ & $\begin{array}{c}\text { Harvest } \\
\text { date }\end{array}$ \\
\hline 1 & Frost Nucellar & mid & 90 & 7 & 3 & 4 & 1996 & 6 Feb. 1997 \\
\hline 1 & Frost Nucellar & mid & 90 & 9 & 4 & 2 & 2001 & 7 Jan. 2002 \\
\hline 1 & Frost Nucellar & mid & 90 & 9 & 4 & 2 & 2002 & 31 Jan. 2003 \\
\hline 1 & Frost Nucellar & mid & 90 & 9 & 4 & 2 & 2003 & 12 Jan. 2004 \\
\hline 3 & Washington & mid & 109 & 2 & 6 & 4 & 2002 & 31 Jan. 2003 \\
\hline 4 & Bonanza & early & 180 & 7 & 3 & 4 & 1997 & 25 Nov. 1997 \\
\hline 4 & Bonanza & early & 180 & 7 & 3 & 4 & 1998 & 10 Dec. 1998 \\
\hline 5 & Tule Gold & early & 180 & 12 & 4 & 4 & 1999 & 29 Nov. 1999 \\
\hline 5 & Tule Gold & early & 180 & 12 & 4 & 4 & 2000 & 27 Nov. 2000 \\
\hline
\end{tabular}

${ }^{z} \mathrm{Mid}$ refers to a navel that is typically picked midseason (late December through March in the San Joaquin Valley), while early refers to a navel picked early (from mid-October through mid-December).

y 100 trees/acre $=247.1$ trees $/$ ha.

Treatments, which included experimental controls, usually involved pruning, fertilizer, thinning agents such as napthaleneacetic acid, or petroleum oils. In most cases, total fruit number for treated trees was not significantly different from that of untreated control trees.

data points were eliminated for any perceived lack of fit. Reported coefficients of determination $\left(r^{2}\right)$ values are adjusted downward based on sample size $(n)$.

\section{Results and discussion}

The objective of this research was limited to determining if the number of commercially valuable sized fruit could be predicted based on total annual fruit production. The determination of the effect that a given treatment, environmental or cultural variable may have had on total annual fruit production was, generally, outside the scope of this study. Variation in total fruit number, necessary for calculation of a reliable CFPF regression equation, appeared to be mostly attributable to differences in fruit set among years. Navel orange does not demonstrate the degree of alternate bearing present in some citrus species and yield has been negatively correlated with high temperatures that occur some years in the southern San Joaquin Valley during fruit set (Jennings, 1934; Jones and Cree, 1965). However, cultural or other unknown factors limited or may have limited fruit number some years. Experimental treatments applied to trees in the six experimental orchards varied, and, generally, total fruit number per tree and number of commercially valuable fruit per tree that resulted from experimental treat- ments were not significantly different from controls. In Orchard 1 , pruning treatments affected the total number of fruit produced per acre in crop year 2000 and 2003, as did manual thinning, petroleum oil or napthaleneacetic acid treatments in Orchard 4 in 1997 and 1998 and Orchard 5 in 1999. Insects or mites were not significant contributors to effects on yield, fruit quality or fruit size during the years that studies were conducted in these orchards.

THE MIDSEASON COMMERCIAL FRUIT PRODUCTION FUNCTION. FOr midseason varieties only, the CFPF was positive, linear and highly significant when fruit production was between 14,000 to 130,000 fruit/ acre (Figs. 1 and 2), which broadly

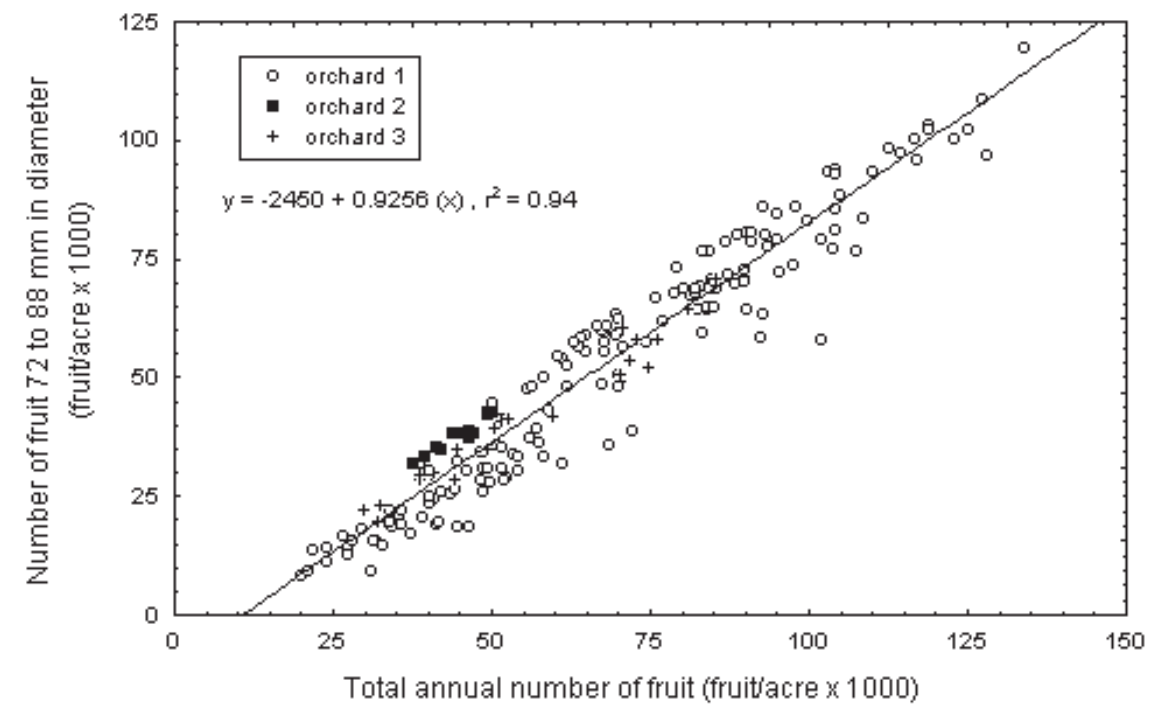

Fig. 1. Relationship between total annual fruit production vs. the number of commercially valuable sized fruit produced for three midseason navel orange orchards (fruit mature late December through March) in the southern San Joaquin Valley of California. Data in Orchard 1 are from 1996 and 2000-03; Orchard 2 are from 2000; and Orchard 3 from 2001 and 2002. Each point is the average of two, four, or 10 trees. The year refers to the year in which the crop bloomed, which for midseason varieties is not necessarily the same as the year of harvest (1000 fruit $/$ ha $=404.7$ fruit $/$ acre, $25.4 \mathrm{~mm}=1$ inch $)$. 
encompasses average fruit production in the southern San Joaquin Valley of approximately 60,000 fruit/acre (O'Connell et al., 2002). The total number of fruit produced annually varied with orchard (Fig. 1) and with year (Fig. 2) but the coefficient of determination of the CFPF remained highly significant. The CFPF (Figs. I and 2 ) suggests that midseason navel orange orchards should not be chemically or hand-thinned as reduced total fruit number reduced the number of valuable fruit. Greater fruit number meant more valuable sized fruit in these three midseason orchards and demonstrates why navel fruit thinning frequently results in reduced economic return to growers (Davis et al., 2004). Low annual fruit production resulted in a large proportion of fruit outside the valuable-sized-fruit category being oversize with diameters greater than $88 \mathrm{~mm}$ whereas high annual fruit production resulted in a higher proportion of less valuable sized fruit being undersize with diameters less than $72 \mathrm{~mm}$ (data not shown). The CFPF y-intercept and coefficient for a late maturing navel orange orchard might not be expected to be the same as for midseason orchards. Late-season fruit drop would reduce total number of harvested fruit and late season fruit growth would likely alter the number of commercially valuable sized fruit.

The EARLY COMMERCIAL FRUIT PRODUCTION FUNCTION. Early maturing varieties had a positive, linear and highly significant CFPF when fruit numbers were 12,000 to 63,000 fruit/ acre (Fig. 3). Within this range of fruit numbers, the intercept and the slope of the CFPF for early maturing fruit were not significantly different from those of the midseason varieties. However, when total annual fruit production exceeded 63,000 fruit/acre, the reliability of the CFPF collapsed (Fig. 3) regardless of the orchard (Fig. 4) or bloom year (Fig. 5). With these early maturing orchards, production of more than 80,000 fruit/acre seldom resulted in a greater number of commercially valuable sized fruit per unit of land area (Fig. 3). The number of commercially valuable sized fruit decreased, in most early maturing orchards, when total annual fruit production exceeded 80,000 fruit/acre (Fig. 4). Even if the number of valuable sized fruit remains constant at about 70,000 fruit/acre, when total fruit production exceeds

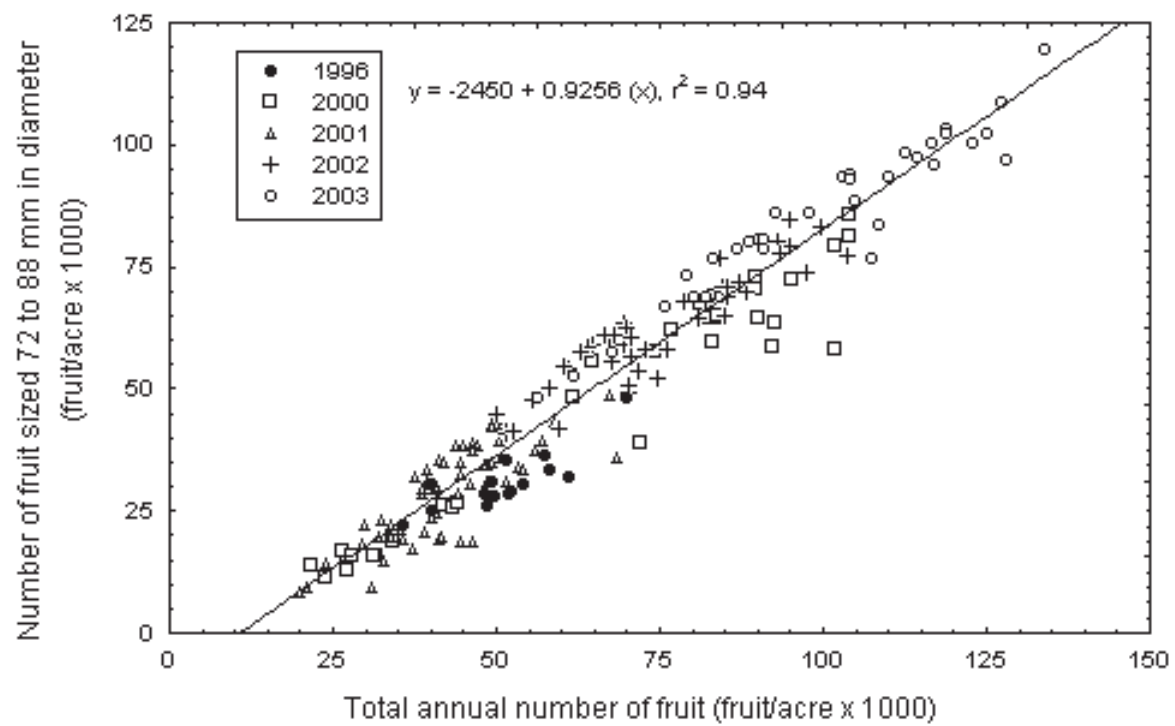

Fig. 2. Relationship between total annual fruit production vs. the number of commercially valuable sized fruit produced by year for midseason navel orange varieties (fruit mature late December through March) in the southern San Joaquin Valley of California. The data are from Orchards 1, 2, and 3. Each point is the average of 2,4 , or 10 trees (1000 fruit/ha $=404.7$ fruit/acre; $25.4 \mathrm{~mm}=1$ inch).

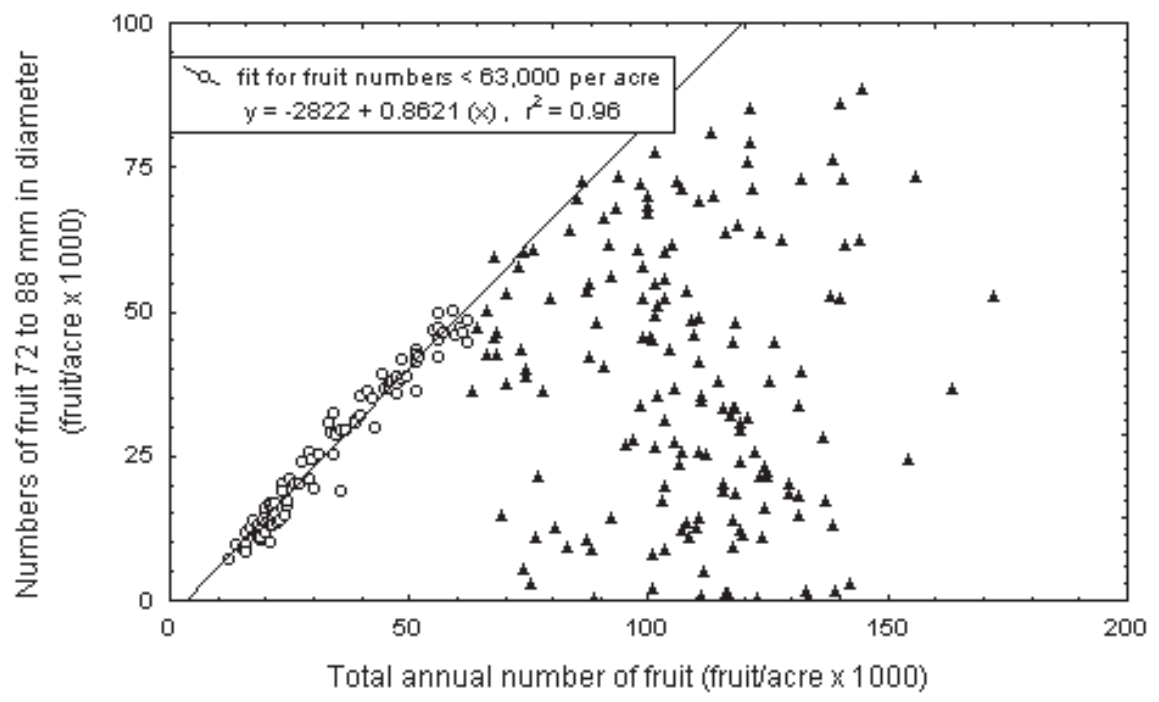

Fig. 3. Relationship between the total annual fruit production vs. the number of commercially valuable sized fruit produced for early maturing navel orange varieties (fruit mature mid October to mid December) in the southern San Joaquin Valley of California. Data from Orchard 4 are from 1997-98; Orchard 5 from 1999-2002 and Orchard 6 from 1998. The regression line was calculated for only total annual fruit numbers less than 63,000 fruit/acre (open circles). A total annual fruit numbers greater than 155,000 fruit/ha is represented by solid triangles. Each point is the average of two or four trees (1000 fruit/ha $=404.7$ fruit/acre, $25.4 \mathrm{~mm}=1$ inch).

81,0000 fruit/acre, the relatively high proportion of smaller fruit in these early maturing orchards would reduce picking efficiency (Lee, 1962; Whitney et al., 1995) and grower profit as handling of small fruit often does not recover picking, transportation and packing costs (O'Connell et al., 2002).

APPLICATIONS AND DISCUSSION OF THE COMMERCIAL FRUIT PRODUCTION Function. The data in Fig. 3 for early-maturing 'Bonanza' and 'Tule Gold' trees suggest reducing total fruit number to a value in the 
range of 63,000 to 80,000 fruit/acre, depending on orchard and year, would maximize the number of valuable sized fruit, minimize the number of small fruit, and prevent a severe reduction in fruit size that can occur in earlymaturing orchards when fruit set is excessive. The unreliability of a CFPF for early-maturing varieties when total fruit number was high illustrates why growers no longer plant, and are removing existing 'Bonanza' and 'Tule Gold' trees. More recently released early navel varieties, such as the 'Beck', 'Newhall' and 'Fukumoto' navel, anecdotally appear better able to produce a higher proportion of commercially valuable fruit than 'Bonanza' or 'Tule Gold' varieties when fruit set is high. The existence of the CFPF provides a framework for comparing yield characteristics of varieties such as 'Beck' and 'Newhall' to 'Bonanza', 'Tule Gold' and the midseason varieties based on relatively few data points. If yields are greater than 81,000 fruit/acre and data points relating total yield to marketable yield fall below the CFPF (Fig. 3 ), the potential of the newly released early varieties to produce valuable fruit would be less than that of midseason varieties and more similar to the older early-maturing varieties.

The CFPF may be useful in evaluating the results of other experiments. For example, the CFPF suggests in years of heavy fruit set that a reduction in total fruit number per unit area in these early maturing 'Bonanza' and 'Tule Gold' orchards might increase the number of the most valuable sized fruit in years when total fruit production exceeds 63,000 fruit/acre. The potential utility of the CFPF for evaluating fruit thinning in an earlymaturing orchard is demonstrated by examining the results of a previous study (Kallsen, 2001). Results from the experimental orchard used by Kallsen (2001) have been included in the data set for this paper and are identified as from Orchard 4. Thinning with concentrated oil applications significantly increased the number of commercially valuable fruit in Orchard 4 (Kallsen, 2001) especially in 1998. However, had the author been aware of the CFPF at the time of publication, the results could have been put in the context of the unusually poor potential of that orchard to size fruit in years with a heavy fruit set. Using the oil treatments for thinning may not be

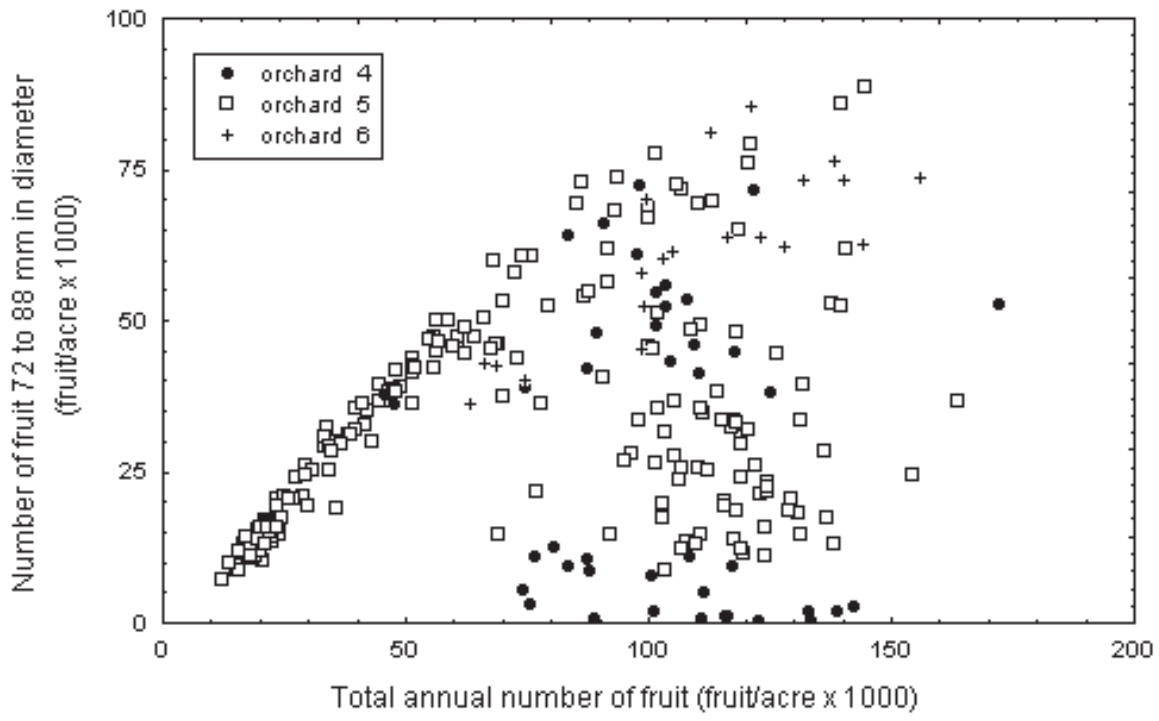

Fig. 4. Relationship between total annual fruit production and the commercially valuable sized fruit produced for early maturing navel orange varieties (fruit mature mid-October to mid-December) from three orchards in the San Joaquin Valley of California. Data in Orchard 4 are from 1997 and 1998; Orchard 5 are from 1999 - 2002; and Orchard 6 from 1998. Each point is the average of two or four trees (1000 fruit $/ \mathrm{ha}=404.7 \mathrm{fruit} /$ acre, $25.4 \mathrm{~mm}=1 \mathrm{inch}$ ).

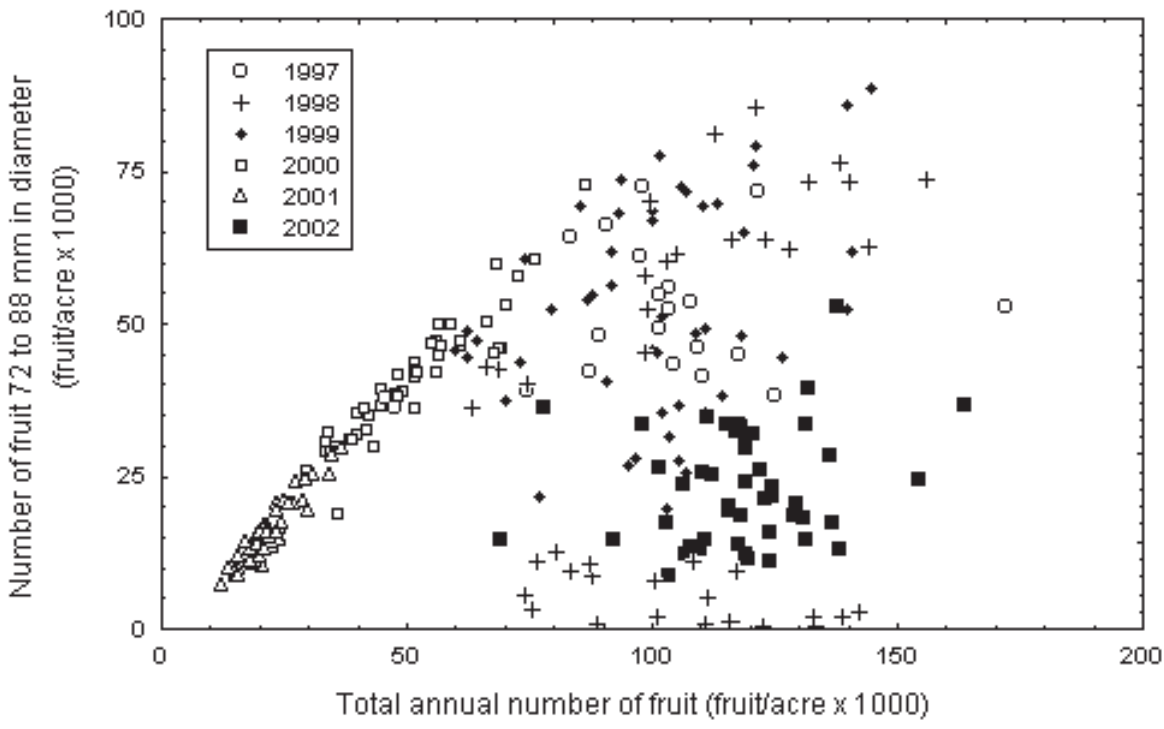

Fig. 5. Relationship between total annual fruit production and the commercially valuable sized fruit produced for early navel orange varieties maturing (fruit mature mid October to mid December) by year from three orchards in the San Joaquin Valley of California. The year refers to the year in which the crop bloomed which is the same as the year of harvest for these early-maturing orchards. Each point is the average of two or four trees (1000 fruit/ha $=404.7$ fruit/acre, 25.4 $\mathrm{mm}=1$ inch $)$.

successful in an orchard with a pattern of fruit set conforming to the CFPF. The data from this Orchard 4 in 1998 also demonstrated the modest increase in fruit sizes that occurred as a result of thinning in relation to the possibilities suggested by the CFPF for midseason varieties (Figs. 4 and 5 ). In orchards with early maturing navel varieties and in seasons with high fruit set, an estimate of fruit number per unit land area in a given orchard relative to the CFPF could assist the grower in deciding if tree or fruit thinning or heavy pruning might prove economically viable. In a similar fashion, the CFPF could be used to evaluate fruit size relations in breeding program selections. The 
CFPF establishes a baseline for estimating the existing relationship between commercially valuable sized fruit and total fruit. A higher proportion of valuable yield to total yield than that marked by this baseline should be a useful trait in any potential new navel orange variety.

\section{Literature cited}

Boswell, S.B., L.N. Lewis, C.D. McCarty, and K.W. Hench. 1970. Tree spacing of 'Washington' navel orange. J. Amer. Soc. Hort. Sci. 95:523-528.

Boswell, S.B., C.D. McCarty, K.W. Hench and L.N. Lewis, 1975. Effect of tree density on the first ten years of growth and production of 'Washington' navel orange trees. J. Amer. Soc. Hort. Sci. 100:370-373.

Davis, K., E. Stover, and F. Wirth. 2004. Economics of fruit thinning: A review focusing on apple and citrus. HortTechology 14:282-288.

Goldschmidt, E.E. and S.P. Monselise. 1977. Physiological assumptions toward the development of a citrus fruiting model. Proc. Intl. Soc. Citricult. 2:668-672.

Jennings, R.F. 1934. Effect of weather in influencing navel yields. Calif. Citrograph 20:34-35.
Jones, W.W. and C.B. Cree. 1965. Environmental factors related to fruiting of Washington navel oranges over a 38year period. Proc. Amer. Soc. Hort. Sci. $86: 267-271$.

Kallsen, C.E. 2001. Petroleum oils as navel orange fruit thinning agents. Hort Technology 11:189-193.

Lee, B.W. 1962. Hedging and topping of mature valencia orange trees. Calif. Citrograph 48:42, 52, 53

O’Connell, N., K. Klonsky, M. Freeman, C. Kallsen, and R. De Moura. 2002. U.C. Cooperative Extension. Sample costs to establish an orange orchard and produce oranges. San Joaquin Valley-south. ORVS-02. 17 Sept. 2004. <http://www. agecon.ucdavis.edu/outreach/crop/coststudies/2002OrangeSJV.pdf>.

Parker, E.R. 1934. Some effects of thinning orange fruits. Univ. of Calif, College of Agr., Agr. Expt. Sta. Bul. 576.

Whitney, J.D., T.A. Wheaton, W.S. Castle and D.P.H. Tucker. 1995. Tree height, fruit size, and fruit yield affect manual orange harvesting rates. Proc. Fla. State Hort. Soc. 108:112-118. 